\title{
Analysis of the Profitability of Okra production among Small holder Okra farmers in Akinyele Local Government Area, Oyo State, Nigeria
}

\author{
Osalusi, C.S. ${ }^{1}$; Akanni-John, Rachael ${ }^{1}$; Okeke E.N² and Ogunsola, J.O ${ }^{1}$
}

${ }^{1}$ Federal College of Forestry, P.M.B 5087, Ibadan, Nigeria.

${ }^{2}$ Federal College of Forestry and Mechanization, Afaka, Kadunna, Nigeria.

Corresponding email: uwanosalu@yahoo.com

\begin{abstract}
The study was carried out to analyse the profitability of okra production among small holder okra farmers in Akinyele local government area, Oyo state. Multi-stage and purposive sampling technique was used in data collection. A total of 75 respondents were sampled. Statistical tools such as frequency distribution, production function and budgetary analysis were used in analyzing the data for this study. The result shows that most of the respondents were male (90.7\%) and married (73.3\%). The major problems faced by the respondents in the study area include, inadequate transport facilities, weather condition and high cost of input. The estimated costs and return of Okro producers realized per okra farmer per annum were $161,137.00$ and 77,317.76 respectively. Okra farming is lucrative in the study area with profitability index of 56.38 and a rate of return on investment of $117.50 \%$ and operating cost ratio of $38.59 \%$.
\end{abstract}

Keywords- Okro, Production, Gross margin, Budgetary.

\section{INTRODUCTION}

Okra (Abelmoschus esculentus) (L) Moench) is an annual fruit vegetable crop belonging to the Malvaceae family. Abelmoschus has several cultivated species of economic importance, two of which was identified as Abelmoschus esculentus and Abelmoschus caillei (Siemonsma, (Siemonsma, 1982). Varieties vary by plant height, size of fruit, colour, early or late maturity etc. and they are namely; white velvet, green velvet, long pod, lady finger, dwarf green pods (Udoh et al., 2005. Vegetables are among the stable food component whose production has continued to increase in most countries of the world. (Udoh and Akpan 2007). They are important protective food for the maintenance of health and prevention of diseases. They contain valuable food ingredients, which can be successfully utilized to build up and repair the body (Bakhru, 2003; Edet and Etim, 2007). The level of vegetable consumption in Nigeria is rising annually owing to the greater appreciation of their food value. (Haruna, 2003). According to Kebede and Gan, (1999), the source of farm income for small and limited resources farmers are basically arable crop production, Vegetable and non-vegetable crops. Its importance has been long recognized all over the world (Ndaeyov et al, 2007). In Nigeria, okra is grown basically in all the states of the federation both as rain fed and irrigated crop because of the highlighted values. Also, it serves as a source of income to its producers, labourers and marketers (Alimi, 2004). Production of these vegetables, especially okra as a small scale enterprise can financially empower the farmers especially those with little capital, limited access to land and working under labor constraints. (Lewis 1997). The cash they provide contributes significantly to the food security at the house hold level and enables farmers to attain a degree of independence within the family budget. This study examined how profitable okra production is among small holder okra farmers Akinyele local government area.

\section{MATERIALS AND METHODS}

Study area

The study was carried in Akinyele local government area, Oyo state, Nigeria. Akinyele Local Government area was created in 1976 with the administrative headquarters located in Moniya. The Local Government shares the same boundaries with Afijo local government to the north, Lagelu local government area to the east, Ido local government area to the west and Ibadan north local government area to the south. The area lies between the latitude $7.5309^{\circ} \mathrm{N}$ and longitude $3.9110^{\circ} \mathrm{E}$, it occupies a land area of 464.892 square kilometers with a population density of 516 persons per square kilometers. Using $3.2 \%$ growth rate from 2006 census figures, the 2010 estimated population for the local government is 239,745 . It is 
dominated by the Yoruba's among other resident tribes such as Ibo, Tiv, Hausa, Nupe, Fulani etc. The residents are of Christianity, Islamic and traditional religion. The people of the local government are predominantly farmers who mostly involve in crop production such as cassava, pepper, yam, maize and vegetables, while some are youths who are involved in trading and other businesses. Akinyele Local Government is highly heterogeneous and metropolitan in nature especially in areas like Ojoo, Orogun, Shasha, Moniya and Akinyele where Nigerians from different tribes and foreign Nationals resides.

\section{Sampling Techniques}

Multi stage and purposive sampling technique was employed for this research. The first stage involves the selection of the study area, Akinyele local government area was purposively selected based on a prior knowledge that it is an okra producing area and contains a considerable amount of okra farmers. The first stage involved stratified sampling which was used in grouping the various villages in Akinyele Local Government Area. The second stage involves the simple random selection of $50 \%$ of the total number of the afore mentioned wards in the study area i.e. 6 wards out of the 12 wards which are ward1-Ikereku, ward4 -Olode/ Amosun/ Onidundu, ward5 -Oje-emo / Moniya, ward7: Iwokoto/ Talonta / Idioro, ward11: Olorisa-oko/ Okegbemi/ Mele, ward12: Iroko. The third stage involved random selection of three communities in each town making five (5) communities. A list of such farmers was collected from the respective community's council of baales and Oyo State A.D.P (Agricultural Development programme). A total of seventy-five (75) respondents was used for the study.

\section{METHOD OF DATA ANALYSIS}

Statistical tools such as frequency distribution, Gross Margin and Net income analysis. Afolami (2002) defined gross margin analysis as the difference between the gross farm income (GFI) and the total variable production cost (TVC); while the Net farm income (NFI) was defined as the difference between gross margin and total fixed production cost.

\section{Budgetary Model}

$\mathrm{GM}=\mathrm{TR}-\mathrm{TVC}$

Where
$\mathrm{GM}=$ Gross margin ( $\$$ /respondent/annum)

$\mathrm{TR}=$ Total revenue ( $\$ /$ respondent/annum)

TVC $=$ Total variable costs $(\mathrm{N} /$ respondent/annum)

$\mathrm{NFI}=\mathrm{GM}-\mathrm{TFC}(\AA /$ respondent/annum $)$

Where

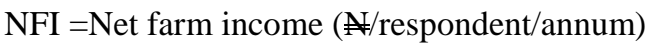

TFC $=$ Total fixed cost ( $\# /$ respondent/annum)

In addition, various profitability indices were computed. They are:

Profitability Index $(\mathrm{PI})=$ NI/TR X100

Rate of Return on Investment $(\mathrm{RRI})=$ NI/TC X $100 \%$

Operating Cost Ratio (OCR) = TVC/TR X 100\%

PI was used to determine the extent to which investment in okra farming in the study are is profitable; RRI was used to measure the percentage of profit derived from an investment outfit; while OCR was used to estimate the relative expenditure structure in the okra farming business.If, PI is greater than 1 , the business is profitable; RRI is greater than 1, the investment is profitable; OCR greater than 1 , it is profitable to invest on the project.

\section{RESULTS}

Table 1 shows the Socio-Economic Characters of Okro farmers in the study area. The table shows that $90.7 \%$ of the Okro farmers were male. This means that males dominated okra farming in the study area which might be due to the fact that okra farming might be too tedious for females especially the process of land preparation. It is observed from the study that the highest percentage (36.0\%) of respondents were at age bracket of 21-30 years. This supports proposition of Madur (2000) who said that older people of older ages are more into farming than younger people in Africa. The result also shows that majority of the okra farmers in the study area $(58.7 \%)$ had first school leaving certificate while $40.0 \%$ had no formal education. This means that majority of the okra farmers in the area can read and write. This is line with Swanson (2008) education enables farmers to make informal decision regarding production and marketing of their produce. Findings also shows that $90 \%$ of the plantain farmers had a household size of less than 4 people, the large household size showed available labor for okra production in the study area. Enete and Okon, (2013) reported a large household size in the area serves as cheap source of family labour. 
Table 1: Socio-Economic Characteristics of Respondents



Source: Field survey, 2019

\section{Budgetary Analysis Results}

Table 2 presents the average costs and returns of okra production in the study area. Total revenue of $\$ 161,137.00$ was realized per okra farmer per annum. The total cost of 77,317.76 was incurred. Of this, variable cost constituted about $62,188.88$. The breakdown of the variable costs is shown in Table 2 below. A financial and Net Income of 90,848.12 was realized per okra farmer in a year. This is agreement with Oladimeji and Abdulsalam (2014) who found out that dry season irrigated farming in Asa River, Kwara State, Nigeria, has a net margin per hectare of $\$ 62,501.10$ meaning a profitable venture. This indicated that okra production is profitable in the study area. Okra farming is lucrative in the study area with profitability index of 56.38 and a rate of return on investment of $117.50 \%$ and operating cost ratio of $38.59 \%$. The okra farmers are primarily interested in selling their outputs to raise income and probably satisfied the household's food need or subsistence. Thus, the okra farmers like any other entrepreneur may have a profit motive.

Table.2: Costs and Revenue Per Okra Farmer Per Annum

\begin{tabular}{lr}
\hline VARIABLES & $161,137.00$ \\
\hline TOTAL REVENUE & \\
VARIABLE COST & \\
\hline
\end{tabular}

\begin{tabular}{lr}
\hline Seeds & $4,172.06$ \\
Fertilizer & $9,562.50$ \\
Herbicide & $2,891.81$ \\
Labour & $39,375.00$ \\
Transportation & $6,187.50$ \\
Total variable cost & $62,188.88$ \\
Fixed cost items & \\
Cutlass & $1,950.00$ \\
Hoe & $1,800.00$ \\
Basket & 350.00 \\
Land charges & $3,000.00$ \\
Knife & $1,000.00$ \\
Total Fixed Cost & $8,100.00$ \\
SUB-TOTAL & $70,288.88$ \\
Contingency (10\%) & $7,028.89$ \\
Total Cost & $77,317.76$ \\
Gross Margin & $98,948.13$ \\
Net Income (NI) & $90,848.12$ \\
Profitability Index (\%) & 56.38 \\
Rate of Return on Investment $(\%)$ & 117.50 \\
Operating Cost Ratio (OCR) $(\%)$ & 38.59 \\
\hline Source: Computed
\end{tabular}

Source: Computed from field survey data, 2019

\section{Constraints Associated With Okro Production}

The result of analysis of constraints encountered by okra farmers in the study area ranked from most critical to the least showed that pest and diseases took the lead indicated 
by $17.3 \%$. This was followed by the inadequate transportation facilities $(16.2 \%)$, weather condition $(16 \%)$ and high cost of input (14.7\%) It is interesting to note that these three constraints identified as most important constraints sum up to over half $(58.2 \%)$ of the problems of vegetable farmers in the study area. It may be concluded that if these four constraints are looked into, other impediments such as 5th, 6th and 7th constraints may cease to exist or reduce to minimum in the study area.

Table.3: Constraints faced by Okro farmers in the study area

\begin{tabular}{|c|c|c|c|c|}
\hline S/N & Constraints* & Frequency & Percentage & Rank \\
\hline 1 & Lack of credit facilities & 10 & 13.3 & $5^{\text {th }}$ \\
\hline 2 & Pest and diseases & 13 & 17.3 & $1^{\text {st }}$ \\
\hline 3 & Poor storage facilities & 8 & 10.3 & $7^{\text {th }}$ \\
\hline 4 & Weather condition & 12 & 16 & $3^{\text {rd }}$ \\
\hline 5 & Inadequate capital & 9 & 12.2 & $6^{\text {th }}$ \\
\hline 6 & High cost of input & 11 & 14.7 & $2^{\text {th }}$ \\
\hline 7 & $\begin{array}{c}\text { Inadequate } \\
\text { transportation facilities }\end{array}$ & 12 & 100.0 & \\
\hline
\end{tabular}

*Multiple responses

Source: Field survey, 2019

\section{CONCLUSION AND RECOMMENDATIONS}

The study was carried out to investigate the profitability of okro production among small holder farmers in Akinyele Local Government Oyo State, Nigeria. The finding shows that most of the respondents were male and married and they were still at middle-age group On the basis of this study, the major problems faced by the respondents in the study area include, inadequate transport facilities, weather condition and high cost of input.

Based on the study findings, the study recommends the need for government to provide inputs such as chemicals (pesticides and herbicides) planting seeds etc at subsidized rates to farmers and also aim at solving major problem of vegetable production. Also, good road networks should be provided by the government (state or federal, where applicable) to aid easy movement of farm produce to the designated locations.

\section{REFERENCES}

[1] Alimi, I., (2004). Use of Cultural Practices and Economic Impact of Insecticide Use, Awareness and Practice of Insecticide Safety Precaution on Okra Production 10 (1):23-36.

[2] Bakhru, H. K. (2003): Foods That Heals. The Natural Way to Good Health. Orient Paperbacks, Delhi Pp. 82 90.

[3] Edet, G. E. and Etim, N. A. (2007): Gender Role in Fluted Pumpkin (Telifera occidentalis) Production in Akwa Ibom State. Proceedings of the $41^{\text {st }}$ Annual Conference of the Agricultural Society of Nigeria (ASN) held at Zaria, $22^{\text {nd }}$
[4] Enete A.A., Okon, U.E. (2010): Economics of Vegetable (Talinum triangulare) Production in Akwa Ibom State, Nigeria. Field Actions Science Report (online). 2010; 4. Accessed 17 June, 2019.

[5] Haruna, U. (2003): Strategic Options for Profitable Marketing of Fadama Crops. A paper presented at the MTRM, SAPD Headquarters, Bauchi. February 17 18.Pp 8.

[6] Kebede, E. and Gan, J. (1999): The Economic Potential of Vegetable Production For Limited Resources Farmers in South,Central Alabama. Journal of Agribusiness, Vol. 7, No. 1, Pp. 63-75.

[7] Lewis, I. (1997). Network vegetable production Africa: its contribution to conservation and use of traditional vegetables, in Traditional African Vegetables. Proceedings of the IPGRI International Workshop on Genetic Resources of Traditional Vegetables in Africa. Pp. 159 160

[8] Madhur, H. (2000): Information and Communication Technologies for Rural Development and Food security; Lesson from Field Experiences in Developing Countries. Pp. 23-37.

[9] Ndaeyo, N. U., Harry, G. I. and Indongesit, N. E. (2007): Growth of Celosia argentia L., as influenced by the Complementary Use of Organic and Inorganic Fertilizers. Proceedings of the $41^{\text {st }}$ Annual Conference of the Agricultural Society of Nigeria (ASN) held at

Samaru Zaria from $22^{\text {nd }}-26^{\text {th }}$ October, Pp $62-72$.

[10] Oladimeji, Y. U and Abdulsalam, Z. (2014): An Economic Analysis of Dry Season Irrigated Vegetables.

[11] Siemonsma, J.S (1982); The Cultivation of Okra (Abelmoschus spp), Tropical Fruit Vegetable (with special reference to the Ivory Coast) D.H.O, thesis, Wageningen Agricultural, Wageningen, the Netherlands. 297pp.

[12] Swanson, B. (2008): Global Review of Good Agricultural Extension and Advisory Service Practices. 
[13] Udoh, E. J. and Akpan, S. B. (2007): Measuring Technical Efficiency of Water Leaf (Talinum triangulare) Production in Akwa Ibom State Nigeria. America Eurasian Journal of Agriculture and Environmental Science. Vol. 2, No. 5, Pp. 578 - 22

[14] Udoh, D.J. Ndon B.A. Asuquo P.E. and Ndaeyov N.U. (2005). Crop Production Techniques for the Tropics Concept Publisher, Lagos, Nigeria, pp223-247. 